\title{
Prospects for the development of culture in Uzbekistan
}

\author{
Abdullo Saidkhonov Sadrullo Ogli ${ }^{1}$ \\ ${ }^{1}$ A student of the State Conservatory of Uzbekistan \\ Email:s aidkhonov98@mail.ru
}

\begin{abstract}
This article discusses the role of art in the development of the nation, its spiritual maturity, its importance, its relevance as an important factor for national revival, which is why the necessary attention is paid to the development of various aspects of art.
\end{abstract}

Keywords: spirituality, culture, development, music, education, art, music, Action Strategy, maqom, composer

\section{INTRODUCTION}

President Sh. Mirziyoyev's opinion shows that spirituality is closely connected with human life: Man always needs spiritual nourishment. If he does not get this food from the environment in which he lives, or if this environment does not satisfy him, then he will gradually look for such food elsewhere.

From time immemorial, the role of art in the development of the nation, in its formation as spiritually mature and perfect has been great. Today, we see that its importance and relevance is an important factor for national revival, which is why the necessary attention is paid to the development of various aspects of art. After gaining independence, the Republic of Uzbekistan has made great efforts to develop our national traditions, customs and values and pass them on to the younger generation. Of course, the role of music in this regard is invaluable.

Indeed, on February 7, 2017, in accordance with the Decree of the President of the Republic of Uzbekistan Sh. Mirziyoyev PD-4947, the Action Strategy for the five priority areas of development of the Republic of Uzbekistan for 2017-2021 was signed. This document is aimed at further enhancing the effectiveness of large-scale reforms in the country, creating conditions for the comprehensive and rapid development of the state and society, modernization of the country and the implementation of priorities for liberalization of all spheres of life. In particular, during the video conference held by the President on March 19, 2019, we put forward 5 important initiatives to increase attention to youth, their correct and rational use in the rapidly evolving information technology, to further strengthen their interest in art, culture and sports. .

The First Initiative is aimed at increasing the interest of young people in music, painting, literature, theater and other arts, and revealing their talents.

These Decrees and Edicts created a wide range of opportunities for young people. Today, the number of young people working in the field of music, contributing to its formation, is growing day by day. The measures taken to establish national music schools in Uzbekistan are among the first. First of all, it is necessary to clarify the application of the concept of existing national schools in the context of this article. By this term is meant a term which is able to form its own way, which has its own peculiarities, and which is not connected with space. It is important to cite national status schools as an example.

The development of the art of maqom (in English suite), its application at the state level, was the reason for the formation of the schools we mentioned. In this regard, maqom ensembles, performers, composers, maqom scholars are working in the country. In this regard, the republican competition among composers "The best work on the path of status", international scientific-practical conference programs for musicologists, maqom scholars, specialists and artists on "Young maqom performers" and "Prospects for the development of the art of maqom" are organized.

It should be noted that the speech of President Sh.M.Mirziyoev is very appropriate: "We must all work together to build the immunity of young people. In order to bring up a perfect person in any society, it is especially important to enrich his spiritual world, to instill in his mind the virtues and high moral spirit. [1]

It should be noted that the International Conference of Maqom Art, organized in our country, has been held since 2018 in Shahrisabz, Kashkadarya region. The I Maqom Art International Form was attended by 30 
music ensembles and soloists from 26 countries, more than 30 musicologists and maqom scholars from 18 countries with their scientific views and theses on various topics. Among them, the ensemble "Saqil" under the artistic direction of Honored Artist of Uzbekistan Abdurahmon Kholtoev took one of the first places in the nomination "Best Maqom Ensemble". Indeed, among our young and talented artists are the winner of the International Music Festival of Oriental Songs Mehrinigor Abdurashidova, the winners of the Republican Competition of Performers named after Yunus Rajabi Ochilbek Matchonov, Mansur Voisov, Nabijon Kadyrov, Ilyas Arabov, Bekzod Safarov, Erkin Khudoiberdiev, Gulzoda Khudoynazarova, Boboda, Ziyodahon Ruzimova and a number of similar talents.

To study the scientific work of our ancestors on the development of the art of music, in this regard $\mathrm{Z}$. Aripov writes: "Central Asian scholars and thinkers Farobi, Ibn Sino, Ibn Zayla and Abu Abdullah Khorezmi made a major and decisive contribution to the formation and development of Eastern music in the X-XI centuries. These people, who interpreted the origin of music with a scientific approach without linking it to various myths and religious legends, considered the science of music as an integral part of mathematics [2, p. 3].

The policy of music culture pursued by our state is not limited to the formation and development of national music schools. Our talented young people are demonstrating their skills and abilities by performing masterpieces of world classics on the big stages of the world. In this regard, the winner of international competitions among violinists Muslimahon Makhkamova, winner of international competitions, virtuoso violinist Sardor Dzhumaev, winners of international competitions Aziz Shokhakimov who achieved to conduct the orchestras of a number of states like Bamberg, Saxony, Germany, Monte Carlo, Poland, Japan and other countries, and other winners and laureates of national and international competitions Alibek Kabdurahmanov, Kamoliddin Urinbaev, Alla Sorokoletova, Maria Zhukova, Vlada Guseynova, Lemara Ablyatifova, Guzal Sultanova, Dilyara Islyamova, Darkhon Kamilov, Sabina Tursunova, Sardor Ibragimov, Sanjar Azimov, Abdurasul Kushmakov, winners of the State Prize "Zulfiya" Nodira Dadamuhammedova, Inoyatkhon Abdullaeva, conductors Alibek Kabdurahmanov, Kamoliddin Urinbaev and we can cite the names of our talented young people like them.

The young people of Uzbekistan are demonstrating their talents in a number of countries around the world with their knowledge in creating works that meet the requirements and standards of classical music. The State Conservatory of Uzbekistan and the Union of Composers of Uzbekistan have made a significant contribution in this direction, and we can cite the I International Festival of Young Composers as a source of joy for their cooperation. At the Festival, which was held for the first time in June 2019, 17 talented young composers from Uzbekistan, Karakalpakstan, Kazakhstan, Kyrgyzstan, Tajikistan and Turkmenistan presented their works in various genres. Among the composers who represented our country, works by Kamolliddin Azimov, Farkhod Nazarov, Mehroj Mukhtorov, Sherzod Sobirov, Nurali Erkaev were performed as part of the festival.

Our young artists do not limit themselves to genres and forms, but also do not lag behind the world's youth in the creation of works that meet the requirements of modern music, combining its unique, mysterious aspects.

It should be noted that the regional branches of the Union of Composers of Uzbekistan, headed by experts in their field, masters of arts, composers Rustam Abdullaev and Habibulla Rakhimov, are moving in a planned and purposeful way. The management with many years of experience provides suggestions and instructions on the development of the industry, youth creativity, scientific achievements, expanding the scope of creative dialogue, organizing creative meetings and master classes with well-known and talented composers and musicologists, their spiritual growth is an important step towards their future development as qualified specialists in their field [3.175-176].

The Omnibus Laboratory ensemble has been instrumental in providing the necessary guidance, advice and instructions in the implementation of works created in these areas. Not only our composers, but also our performers can increase their knowledge by the organizers of this ensemble. The ensemble regularly invites composers and creators from around the world to acquaint them with the latest developments in the world of modern classical music, its currents. In particular, concerts, master classes, brefings and various creative meetings of composers and musicians from Germany, France, Italy, the United States and Africa are being held.

It should be noted that our artists are conducting research on the creation of stage productions. In this regard, on the stage of the State Academic Bolshoi Theater of Uzbekistan named after Alisher Navoi, V.A. Mozart's "Marriage of Figaro" ("Свадьба Фигаро"), J. Verdi's "La Traviata", "Troubadour", "Rigoletto", J. Bizen’s "Kamen”, "Pearl Seekers” (“Искатели жемчуга"), "Floria Tosca” by Dj. Puchchini, "Swan Lake" 
("Лебединое озеро") by P.I. Tchaikovsky, "Sleeping Princess" ("Спящая красавиц"), " Nutcracker" ("Щелкунчик"), "Royal Bride" by N. Rimsky-Korsakov ”(“Царская невеста”), S. Prokofev's "Romeo and Juliet", operas and ballets are being staged along with Uzbek composers M. Ashrafi's "Amulet of Love" ("Амулет любви”), М. Mahmudov's “Silver”, U. Musaev's “Tomiris”, R.Abdullaev's "Sadoqat", M.Bafoev's "Hamsa", A.Ergashev's "Humo".

It is noteworthy that our talented young composers are also creating stage works. Among them is the opera-oratorio "Road to Heaven" (Дорого в рай), written by Nurali Erkaev, which has a philosophical and religious content that illuminates the fine lines between good and evil, hell and heaven. This work was first presented to the audience in March 2017 in the Great Hall of the State Conservatory of Uzbekistan. The work is based on the poem of the famous Uzbek poet, statesman, Hero of Uzbekistan Abdulla Aripov, the libretto of the opera-oratorio belongs to the pen of the composer. The play tells the story of a young man who saves a person's life and is left in the lurch, a summary of what he has done during his life. Judging by the content of the oratorio, we are witnessing the spiritual and enlightenment maturity of our youth.

Based on the above thoughts and comments, Uzbekistan, which today has chosen the path of national revival, formation and development, is taking the first steps towards a new renaissance. In the context of this article, we have been able to cite only a part of the youth policy pursued in the country. However, we can see such reforms in all areas and directions. One of the main reasons for the great success of the youth of Uzbekistan, not only in the country but also in the world, is the fact that the country has created all the opportunities, conditions, open and transparent approach to new ideas, thoughts and opinions. The benefits created for future generations are bearing fruit today.

\section{REFERENCES}

1. Mirziyoev Sh.M. Critical analysis, strict discipline and personal responsibility should be the daily rule of every leader's activity. -T., Uzbekistan, 2017.

2. Aripov Z. Oriental musical sources (X-XI centuries). - Tashkent, -2008.

3. Current issues of music art in Uzbekistan: collection - Tashkent: "Music" Publishing House, 2020. - 200 p. 